\title{
The Role of English Language and Literature in Enhancing Students' Language Application Ability
}

\author{
Li Li and Peng Yang \\ Science and Technology Institute of Nanchang University
}

\begin{abstract}
Keywords: English language and literature; Language application ability; Practice teaching methods
\end{abstract}

\begin{abstract}
The application of language is the key of language learning, and English language and literature can largely improve the students' language application ability. The cognition of students is mainly developed in practice activity. Therefore, teachers must make students be active in the process of teaching, let them use their brain and start saying, and participate in the teaching process actively. The paper elaborates the specific composition of language application ability, that is language basic knowledge and related expression techniques, then points out that English language and literature can promote language application ability, mainly because it can enrich expression, expand knowledge and provide examples.
\end{abstract}

\section{Introduction}

Language application is the fundamental purpose of learning a language. New requirements in English writing are put forward to stress putting special emphasis on improving students' ability of thinking and expressing in English. Written expression also accounts for a larger proportion, and its main purpose is to investigate the students' language ability, written communication ability and logical thinking ability, therefore student's higher comprehensive ability is required. The students' compositions fully reflect the grammar knowledge, vocabulary knowledge and phrasing ability they master.

However, the situation is not optimistic. Students have the fear feeling for application ability of English, and the quality of their compositions are low. In classroom teaching, we feel quite a few students can use English for the most simple self-expression. Statements confusion, ambiguity and incomplete sentence structure and punctuation misuses are everywhere. The cognition of students is mainly developed in practice activity. Therefore, teachers must make students be active in the process of teaching, let them use their brain and start saying, and participate in the teaching process actively. In the class, practical English skill must be cultivated, motivating the students through class activities.

The paper introduces how the student can improve their language application ability by English language and literature learning. However, for the specific effects and the reason of such effects, very few people make research on it. To improve the language application ability more targeted by English language and literature, it is necessary for related research.

\section{Teaching Status of Current English Language and Literature}

Bad Learning Attitude. Many students learn English not for interest, but for coping with the exam. Students learn English with psychological burden and incorrect attitude, the actual teaching effect was greatly reduced. In the process of practical English learning, they are in a relaxing state. Students don't attach importance to English learning, so they will not be able to master the correct method of learning English, thus producing a resistance to English.

Less Emphasis of Colleges on English Language Learning. At present, some colleges and universities pay less attention to English language and literature teaching. Especially in some engineering or mechanical disciplines, English teaching is in subordinate position for a long time. Colleges put less emphasis, making the college English teachers limited, and foreign teacher resources even less, software and hardware level fall behind. The English language and literature 
teaching in colleges and universities cannot get the corresponding attention, making the teaching method and teaching means in colleges and universities remain on the basis of the past.

Uneven Teaching Abilities of Teachers. In the current college English language and literature teaching, teachers present the polarization phenomenon. Aged teachers' basic knowledge is relatively strong, but they have traditional teaching idea; Young teachers' thinking is active, and they have multiple teaching methods that can effectively enliven classroom atmosphere.

\section{The Role of English Language and Literature in Improving Students' Language Application Ability}

Rich Expression. The expression of English and Chinese expression owns common points and very big difference. The common ground in expressing emotion and reaching the purpose of expression, the methods are basically the same. In Chinese expression, rhetorical question is usually used to highlight a problem. As a result, these two languages can complement each other. Other emotional expression is the same. English and Chinese use imperative sentence to express strong will and strong emotions more often. At the time of learning English, students will review the expression methods in Chinese literature so as to improve their English; in Chinese communication, students will use the expressing methods in English learning. Such complementation can enrich the students' expression more effectively.

Knowledge Expansion. Any language has its unique historical background. In western countries, for example, number 13 is generally believed to be unlucky, and random visiting is abrupt and offensive. Language is the epitome of the national culture, carrying a lot of historical and cultural customs. Therefore, learning a language can help people to understand a nation, broaden people's field of vision faster, and enrich people's knowledge. The custom of different knowledge cannot enrich the students expand their knowledge.

Good Abstract. In English language and literature, a lot of words are worthy for students reciting directly. In English, recite good texts for a long time and use them directly that can improve the students' literary accomplishment very quickly, make the used words more accurate and concise. At the same time, this sentence can also increase the appeal of language use and realize the expression of language function and emotional communication and influence, to improve the language application ability.

\section{Learning Method of English Language and Literature}

Cultivate Autonomous Learning and Improve the Innovation Ability. During the period of school, teaching mode is to combine the cultivation of classroom autonomic learning with extracurricular autonomous learning ability. There are three level to cultivate and improve the autonomous learning of students gradually, that is willing to learn, will learn, happy. Willing to learn involves learners' emotional factors, such as attitude, sense of responsibility and motivation, and learning strategies will be learned. Both supplement each other, and emotional factors such as learners' attitude, motivation and learning strategies are restricted by English subject characteristics and learning objectives, and the realization of learning depends on the attitude, sense of responsibility and other emotional factors.

Cultivation of Cultural Knowledge. The cultivation of cultural knowledge is one aspect to optimize economic reingistic talent. Cultural quality education is a part of the implementation of quality education. The cultures in different countries and areas reflect more obviously in commercial activities. A country's politics, economics, geography, history, literature and present situation compose its culture. These aspects reflect the cultural connotation of the country from various aspects. At the same time, drawing lessons from and absorbing foreign culture spirit is beneficial to improve their cultural quality.

Cultivation of Practical Learning. English teaching activities have obvious role in promoting students' learning attitude, oral expression and total score. Varieties of classroom activities exercise the abilities of students, and improve their participation awareness of English learning. In the 
activities that students are rare to show the teachers and students their ability, most of the students can join actively, hoping to be able to get the best performance and students gain a sense of achievement to make them willing to join.

\section{Conclusion}

Though the importance of English language and literature learning for students' language application is self-evident, in the daily teaching process, teachers is limited by class, curriculum and hardware conditions and cannot help students in the classroom for learning English language and literature. The author analyzes the specific principle of language and literature in promoting language application, and believes that it will help the first-line teachers trace the source under present teaching situations, improving the language application teaching level with the essence of English language and literature teaching more efficiently.

\section{References}

[1] Fisiak J. Warsaw studies in English language and literature [M]. Peter Lang, 2012.

[2] Guemide B. Teaching English language and literature in non-native contexts: puts the case for teaching literature [J]. Modern English Teacher, 2012, 21:págs. 73-77.

[3] Fisiak J, Kang H K. Recent trends in medieval English language and literature in honour of Young-Bae Park [M]. Thaehaksa, 2005.

[4] Janet Berkovi?. THE BOOK THAT CHANGED THE WORLD The influence of the King James Bible on English language and literature [J]. Kairos Evangelical Journal of Theology, 2011, 05(02).

[5] Sun W. Research on college english language and literature professional teaching methods[C]// Information Technology in Medicine and Education (ITME), 2012 International Symposium on. IEEE, 2012:150-154.

[6] Hanušová S, Havlíčková H, Váňová T. Methodology research at the department of English language and literature[J]. Masarykova Univerzita, 2009.

[7] Hanušová S, Havlíčková H, Váňová T. Methodology research at the department of English language and literature [M]. Masarykova univerzita, 2009.

[8] Nikam M J. Use of Modern Technique in Teaching English Language and Literature [J]. Golden Research Thoughts, 2012.

[9] Sen B K. DDC readymade: a treasury to 15,000 readymade DDC class numbers relating to Indian subjects, English language and literature [M]. Ess Ess, 2008.

[10] Morita H. The domain expansion mechanism of focus in Japanese and English (Language and Literature)[J]. Journal of the Faculty of Foreign Studies Aichi Prefectural University Language \& Literature, 2005, 37.

[11]Honegger T. Riddles, knights, and cross-dressing saints: essays on medieval English language and literature [M]. P. Lang, 2004.

[12] Scholl H, Marzari F, Tricarico P. E-learning Methods in the Teaching Activities of the Department of English Language and Literature at the Faculty of Education in Brno[C]// Bulletin of the American Astronomical Society. Univerzita Pardubice, 2004:858. 